\title{
Investigation of Prins reaction for the synthesis of 2, 4- disubstituted tetrahydropyran derivatives and 1, 3-dioxanes using polyaniline supported acid as reusable catalyst
}

\author{
KALYAN JYOTI BORAH and RULI BORAH* \\ Chemical Sciences Department, Tezpur University (A Central University), Napaam 784028, \\ Tezpur-Assam, India \\ e-mail: ruli@tezu.ernet.in
}

MS received 19 October 2010; revised 5 January 2011; accepted 16 May 2011

\begin{abstract}
The Prins cyclization of homoallyl alcohol with a variety of aldehydes were observed under reflux condition in dichloromethane using both polyaniline supported $\mathrm{TsOH}$ (PANI-TsOH) and $\mathrm{FeCl}_{3}\left(\mathrm{PANI}-\mathrm{FeCl}_{3}\right)$ as reusable acid catalysts with the formation of 2,4-disubstituted tetrahydropyran ether as single product. In case of 4-, 3- and 2- nitro benzaldehydes, the reaction generated acetal of the aldehyde and homoallylic alcohol as single product. Additionally, both catalysts were investigated for the synthesis of 1, 3-dioxane in dichloromethane under reflux and at ambient temperature.
\end{abstract}

Keywords. Prins cyclization; heterogeneous catalyst; solid acid; polymer support; acetal.

\section{Introduction}

The acid catalysed Prins reaction of olefins with carbonyl compounds is an important reaction for carboncarbon bond ${ }^{1}$ formation which can be used to prepare 1,3-dioxane and tetrahydropyran derivatives via cyclization reaction. There are several types of Prins reactions available in the literature. The condensation of simple olefin-aldehyde leads to the formation of 1,3-dioxanes ${ }^{2}$ and coupling of homoallylic alcohol with (scheme 1) aldehyde forms tetrahydropyran derivatives. ${ }^{3}$ The tetrahydropyran ring is widely distributed throughout nature e.g., in carbohydrates and natural products. ${ }^{4}$ Under the classical condition, the Prins cyclization requires strong acid as catalyst (e.g., $\mathrm{HCl}, \mathrm{H}_{2} \mathrm{SO}_{4}$ acid) and high temperature reaction condition which often produces a mixture of products. Specifically, Lewis or Brønsted acids induced polymerization of olefin can severely interfere with desired C$\mathrm{C}$ bond formation. Therefore, research efforts are being directed to develop eco-friendly catalytic routes for the Prins cyclization reaction. Li et al. reported ${ }^{5}$ the scandium triflate catalysed in situ Prins cyclization reactions for the synthesis of tetrahydropyran-4-ol and ethers in chloroform.

\footnotetext{
${ }^{*}$ For correspondence
}

In recent years, the efficient use of non-toxic and more selective supported solid acidic ${ }^{6}$ catalysts have received more attention in different areas of organic synthesis because of their environmental compatibility, reusability, high selectivity, simple operation, cheaper and ease of isolation of the products. As a result, various solid supported catalysts ${ }^{7}$ such as MCM41, Amberlyst-15 ion exchange resin, zeolite, etc., have gained importance in the Prins reactions. The potential use of polymer supported catalysts as heterogeneous and regenerable catalysts in organic transformation make reaction methods more convenient, economic and environmentally benign. Many reactions can be carried out cleanly, rapidly, and in high yields. The reaction can be performed under mild conditions, and product purification is simplified because of the use of an insoluble solid support. Polymer-supported catalysts can also be recycled after use. Generally, the polystyrene-based polymer-bound Lewis acid catalysts show relatively low activity, and the activity of the catalyst decreases due to insufficient stability of the aromatic ring of the polymer and slow diffusion of substrate into the network. Moreover, the actual loading is limited by Lewis acid catalysed cross linking of chloromethyl groups within the polystyrenebased resin. The best method to increase the maximal loading of the carrier material is obtained by using low molecular weight functional polymers. ${ }^{8}$ 


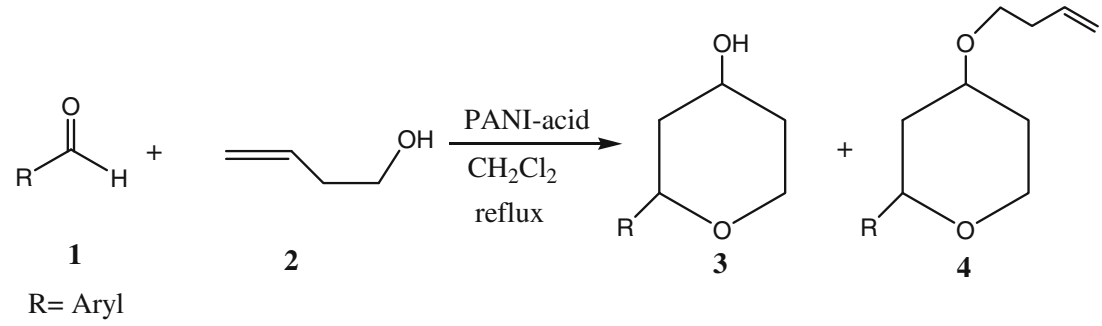

Scheme 1. Prins cyclization of 3-butene-1-ol with aldehyde.

Polyaniline (PANI) is one of the polymers which can be used as a matrix for catalysis. It is cheap, easy to synthesize, light weight with excellent electrical and chemical properties, number of intrinsic redox states, stability and insoluble in a large majority of commonly used solvents, which are the main advantages of supported catalysts. ${ }^{9}$ Many polyaniline supported salts and complexes ${ }^{10}$ ( $\mathrm{TsOH}, \mathrm{H}_{2} \mathrm{SO}_{4}, \mathrm{FeCl}_{3}, \mathrm{AlCl}_{3}$ etc.) are exhibiting excellent catalytic activity with less amount of catalyst in organic synthesis. Polyaniline has acid/base doping response due to presence of different intrinsic redox states. In view of this, we studied the catalytic activity and selectivity of already known polyanilinesupported $\mathrm{TsOH}$ and $\mathrm{FeCl}_{3}$ for the Prins reaction of homoallylic alcohol with different aldehydes and condensation of olefins with paraformaldehyde to produce the corresponding tetrahydropyran derivatives and 1 , 3 -dioxanes ${ }^{11}$ respectively.

\section{Results and discussion}

In continuation of our research interest in the development of environmentally benign syntheses, recently, we have reported ${ }^{11}$ silica-supported $\mathrm{TsOH}$, a suitable acid catalyst for the synthesis of 1,3-dioxane via Prins reaction in solvent-free medium. In this context, we have examined the catalytic activity of TsOH and $\mathrm{FeCl}_{3}$ for the Prins cyclization of 3-butene-1-ol with $p$-chloro benzaldehyde in organic solvents as well as in ionic liquids at different temperatures to form 2, 4-disubstituted tetrahydropyran derivatives. The results are shown in table 1.

But in both cases, less selectivity were observed for the formation of corresponding products. As such no reported work has been found regarding use of polyaniline-supported acid as suitable catalyst to the Prins cyclization. Here we have improved the cataly-

Table 1. Ts $\mathrm{TH}$ and $\mathrm{FeCl}_{3}$ catalysed Prins cyclization of 3-butene-1-ol with 4-chlorobenzaldehyde in different solvents.

\begin{tabular}{|c|c|c|c|c|c|c|}
\hline \multirow[t]{2}{*}{ Entry } & \multirow[t]{2}{*}{ Solvent } & \multirow[t]{2}{*}{ Catalyst } & \multirow[t]{2}{*}{ Temp $\left({ }^{\circ} \mathrm{C}\right)$} & \multirow[t]{2}{*}{ Time(h) } & \multicolumn{2}{|c|}{ Products (Yield \%) } \\
\hline & & & & & 3 & 4 \\
\hline \multirow[t]{2}{*}{1} & \multirow{2}{*}{$\mathrm{CH}_{2} \mathrm{Cl}_{2}$} & $\mathrm{TsOH}$ & \multirow[t]{2}{*}{ r.t. } & \multirow[t]{2}{*}{5} & 38 & 42 \\
\hline & & $\mathrm{FeCl}_{3}$ & & & 35 & 38 \\
\hline \multirow[t]{2}{*}{2} & \multirow[t]{2}{*}{$\mathrm{CH}_{2} \mathrm{Cl}_{2}$} & $\mathrm{TsOH}$ & \multirow[t]{2}{*}{40} & \multirow[t]{2}{*}{8} & 40 & 45 \\
\hline & & $\mathrm{FeCl}_{3}$ & & & 34 & 37 \\
\hline \multirow[t]{2}{*}{3} & \multirow{2}{*}{$\mathrm{CHCl}_{3}$} & $\mathrm{TsOH}$ & \multirow[t]{2}{*}{65} & \multirow[t]{2}{*}{7} & 42 & 40 \\
\hline & & $\mathrm{FeCl}_{3}$ & & & 36 & 39 \\
\hline \multirow[t]{2}{*}{4} & \multirow[t]{2}{*}{$\mathrm{EtOH}$} & $\mathrm{TsOH}$ & \multirow[t]{2}{*}{70} & \multirow[t]{2}{*}{6} & 23 & 15 \\
\hline & & $\mathrm{FeCl}_{3}$ & & & 25 & 17 \\
\hline \multirow[t]{2}{*}{5} & \multirow{2}{*}[\mathrm{bmim}]{$\mathrm{BF}_{4}$} & $\mathrm{TsOH}$ & \multirow[t]{2}{*}{ r.t. } & \multirow[t]{2}{*}{20} & 18 & 20 \\
\hline & & $\mathrm{FeCl}_{3}$ & & & 10 & 15 \\
\hline \multirow[t]{2}{*}{6} & \multirow[t]{2}{*}[\mathrm{bmim}]{$\mathrm{BF}_{4}$} & $\mathrm{TsOH}$ & \multirow[t]{2}{*}{70} & \multirow[t]{2}{*}{12} & 22 & 25 \\
\hline & & $\mathrm{FeCl}_{3}$ & & & 17 & 21 \\
\hline \multirow[t]{2}{*}{7} & \multirow[t]{2}{*}[\mathrm{bmim}]{$\mathrm{PF}_{6}$} & $\mathrm{TsOH}$ & \multirow[t]{2}{*}{ r.t. } & \multirow[t]{2}{*}{12} & 15 & 35 \\
\hline & & $\mathrm{FeCl}_{3}$ & & & 10 & 30 \\
\hline
\end{tabular}

\footnotetext{
${ }^{\mathrm{a}}$ All products were characterized by ${ }^{1} \mathrm{HNMR}$ and also their TLC comparison with authentic sample prepared by reported method
} 
tic activity and selectivity of the Prins cyclization (scheme 1) by refluxing the aromatic aldehydes 1(2 mmol), 3-butene-1-ol 2 (4 mmol) and catalytic amount of polyaniline-supported $\mathrm{TsOH}(0.25 \mathrm{mmol})$ or $\mathrm{FeCl}_{3}(0.25 \mathrm{mmol})$ together in dichloromethane. These two catalysts generated 2, 4-disubstituted tetrahydropyran ether $\mathbf{4}$ as single product from various aromatic aldehydes (table 2, entry 4-8).

Treatment of equal amount of 4-chlorobenzaldehyde $(1 \mathrm{mmol})$ and 3-buten-1-ol (1 mmol) also resulted incomplete of reaction with the formation of 2, 4disubstituted tetrahydropyran ether 4 (table 2 , entry 9) as single product. The selectivity of $\mathrm{TsOH}$ and $\mathrm{FeCl}_{3}$ catalysts were found to be better on the surface of polymer support for the Prins cyclization as compared to non-supported catalysts (table 1). The reusability of the two catalysts was also observed four times without loss of their catalytic activity and selectivity in case of reaction between 4-chlorobenzaldehyde and 3-butene1ol to form the corresponding tetrahydropyran product (table 3). A possible mechanism for this Prins cyclization is shown in scheme 2. Interestingly, the reaction of electron deficient aldehydes like o-, m- and p- nitroben- zaldehydes (table 2, entries 10,11,12) with 3-buten-1ol generated acetal 7 as single product. The presence of nitro group increases the electrophilic character of carbonyl carbon of aldehyde which shows more tendency to react with strong nucleophile like alcoholic group of 3-butene-1-ol to form 7 as the only product. Other aromatic aldehydes prefer to form $\mathbf{4}$ via Prins cyclization due to less electrophilic nature of carbonyl carbon as compared to nitro benzaldehydes.

The stereochemistry of 2, 4-disubstituted tetrahydropyran ether 4 was reported ${ }^{5}$ as cis- based on the coupling constants of the protons at the H-2 and $\mathrm{H}-4$. The presence of an axial-axial coupling was identified from the coupling constant value of approximately $11 \mathrm{~Hz}$ for such protons.

A DEPT study of the three new compounds $(\mathbf{7 d}, \mathbf{7 e}, \mathbf{7 f})$ revealed that (figure 1) each DEPT -135 spectrum shows three negative signals for six $-\mathrm{CH}_{2}$ - groups and different positive signals for seven - $\mathrm{CH}$ - groups while no peaks for two quaternary carbons. In addition, the COSY spectrum of compound $\mathbf{7 d}$ reveals that the signal at $\delta 2.28(\mathrm{q}, \mathrm{J}=6.7 \mathrm{~Hz} \mathrm{C}-2)$ shows large cross peaks with the signals at $\delta 3.47-3.49(\mathrm{C}-1)$ and $\delta 5.73-$

Table 2. PANI-TsOH and PANI- $\mathrm{FeCl}_{3}$ catalysed Prins cyclization of 3-butene-1-ol with various aldehydes in dichloromethane under reflux condition.

\begin{tabular}{|c|c|c|c|c|c|c|c|}
\hline Entry & Aldehyde & Catalyst & Time(h) & $\begin{array}{c}\text { Product } \\
3\end{array}$ & Yield $(\%)$ & $\begin{array}{c}\text { Product } \\
4 / 7\end{array}$ & $\begin{array}{c}\text { Yield }(\%)^{\mathrm{a}, \mathrm{c}} \\
4 / 7\end{array}$ \\
\hline 1 & $\mathrm{C}_{6} \mathrm{H}_{5}$ & $\mathrm{TsOH}$ & 8 & $3 a$ & 40 & $4 a$ & 45 \\
\hline 2 & $\mathrm{C}_{6} \mathrm{H}_{5}$ & $\mathrm{FeCl}_{3}$ & 6 & $3 a$ & 34 & $4 a$ & 37 \\
\hline 3 & $\mathrm{C}_{6} \mathrm{H}_{5}$ & PANI-TsOH & 22 & - & - & $4 a$ & $55^{\mathrm{b}}$ \\
\hline \multirow[t]{2}{*}{4} & $\mathrm{C}_{6} \mathrm{H}_{5}$ & PANI-TsOH & 8 & - & - & $4 a$ & 55 \\
\hline & & PANI- $\mathrm{FeCl}_{3}$ & 9 & - & - & & 50 \\
\hline \multirow[t]{2}{*}{5} & 4-Me $\mathrm{C}_{6} \mathrm{H}_{4}$ & PANI-TsOH & 6 & - & - & $4 b$ & 45 \\
\hline & & PANI- $\mathrm{FeCl}_{3}$ & 6.5 & & & & 42 \\
\hline \multirow[t]{2}{*}{6} & $4-\mathrm{Cl} \mathrm{C} \mathrm{H}_{4}$ & PANI-TsOH & 5 & - & - & $4 c$ & 76 \\
\hline & & PANI- $\mathrm{FeCl}_{3}$ & 6 & & & & 72 \\
\hline \multirow[t]{2}{*}{7} & $2-\mathrm{Cl} \mathrm{C}{ }_{6} \mathrm{H}_{4}$ & PANI-TsOH & 8 & - & - & $4 d$ & 63 \\
\hline & & PANI- $\mathrm{FeCl}_{3}$ & & & & & 57 \\
\hline \multirow[t]{2}{*}{8} & $3-\mathrm{Br} \mathrm{C}_{6} \mathrm{H}_{4}$ & PANI-TsOH & 8 & - & - & $4 \mathrm{e}$ & 60 \\
\hline & & PANI- $\mathrm{FeCl}_{3}$ & & & & & 55 \\
\hline \multirow[t]{2}{*}{9} & $4-\mathrm{Cl} \mathrm{C}_{6} \mathrm{H}_{4}$ & PANI-TsOH & 7 & - & - & $4 c$ & $40^{\mathrm{d}}$ \\
\hline & & PANI- $\mathrm{FeCl}_{3}$ & 8 & & & & 38 \\
\hline \multirow[t]{2}{*}{10} & $4-\mathrm{NO}_{2-} \mathrm{C}_{6} \mathrm{H}_{4}$ & PANI-TsOH & 4 & - & - & $7 d$ & 85 \\
\hline & & PANI- $\mathrm{FeCl}_{3}$ & & & & & 82 \\
\hline \multirow[t]{2}{*}{11} & $3-\mathrm{NO}_{2-} \mathrm{C}_{6} \mathrm{H}_{4}$ & PANI-TsOH & 4.5 & - & - & $7 \mathrm{e}$ & 84 \\
\hline & & PANI- $\mathrm{FeCl}_{3}$ & & & & & 83 \\
\hline \multirow[t]{2}{*}{12} & $2-\mathrm{NO}_{2}-\mathrm{C}_{6} \mathrm{H}_{4}$ & PANI-TsOH & 4 & - & - & $7 f$ & 86 \\
\hline & & PANI- $\mathrm{FeCl}_{3}$ & 6 & & & & 80 \\
\hline
\end{tabular}

${ }^{\mathrm{a}}$ Isolated yields. ${ }^{\mathrm{b}}$ Room temperature reaction. ${ }^{\mathrm{c}}$ All products were characterized by FT-IR, ${ }^{1} \mathrm{HNMR}, \mathrm{CHN}$ analyzer and also their comparison ${ }^{5}$ with authentic sample. ${ }^{d}$ This reactions was carried out in 1 mmol scale with molar ratio 1: 1:0.12 of aldehyde/3-butene-1-ol /catalyst 
Table 3. Recycling of PANI-TsOH and PANI- $\mathrm{FeCl}_{3}$ catalysed Prins cyclization of 3-butene-1-ol with 4chlorobenzaldehydes in dichloromethane under reflux condition.

\begin{tabular}{lcccc}
\hline Entry & Catalyst & Time(h) & $\begin{array}{c}\text { Number } \\
\text { of cycles }\end{array}$ & $\begin{array}{c}\text { Product 4c } \\
\text { Yield (\%) }\end{array}$ \\
\hline 1 & PANI-TsOH & 5 & 1 & 76 \\
& & & 2 & 74 \\
& & & 3 & 75 \\
& & & 4 & 74 \\
& PANI- $\mathrm{FeCl}_{3}$ & 6 & 1 & 72 \\
& & & 2 & 72 \\
& & & 3 & 71 \\
\hline
\end{tabular}

${ }^{\text {a }}$ This reaction was carried out in $1 \mathrm{mmol}$ scale with molar ratio 1: $2: 0.12$ of aldehyde/3-butene-1-ol /catalyst

5.75 (C-3) of 3-butenoxy groups of acetal. The other two compounds (7e, 7f) also showed similar correlations pattern among the three nearby protons at $\mathrm{C}-1, \mathrm{C}-2$ and C-2 of 3-butenoxy group.

Subsequently, we examined the polyaniline-supported PTSA/ $/ \mathrm{FeCl}_{3}$ catalysed Prins reactions of paraformaldehyde and various alkenes in dichloromethane at different temperatures.

These results (table 4, entries 2,7,10,13,15) revealed that both catalysts decrease their reactivity in presence of polymer support for the synthesis of 1,3-dioxane 9 in dichloromethane with respect to $\mathrm{TsOH} / \mathrm{FeCl}_{3}$ catalysts at room temperature. Both supported catalysts showed

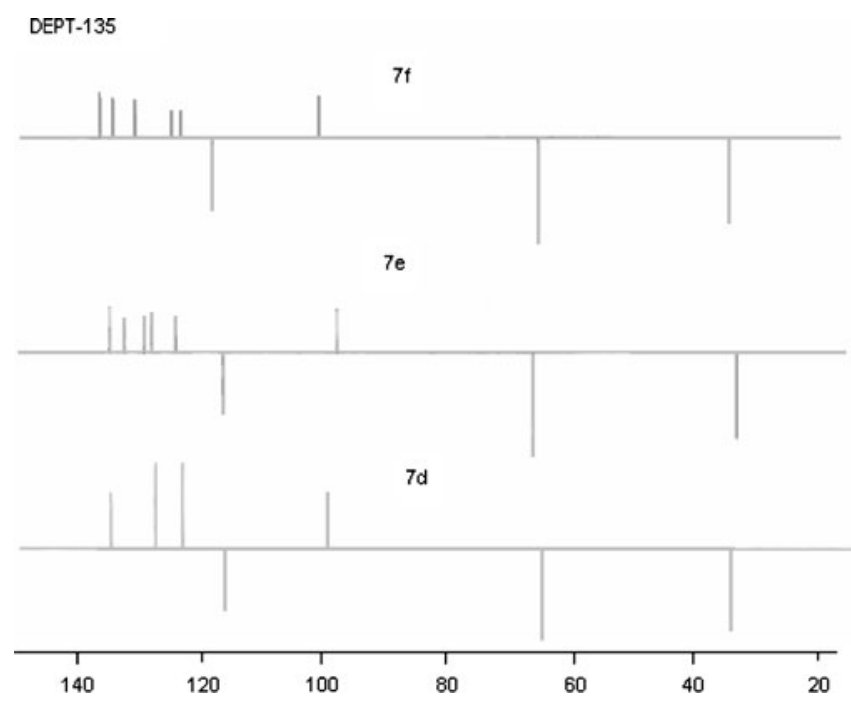

Figure 1. DEPT-135 spectra of $7 d, 7 e$ and $7 f$.

improved results with 1-octene under reflux condition in dichloromethane (table 4, entry 16). Again, the use of formalin was found to be efficient in certain cases under reflux condition within short time (table 4, entries $8,17)$.

\section{Experimental}

\subsection{General information}

All chemicals are commercially available and were used without further purification. The products were

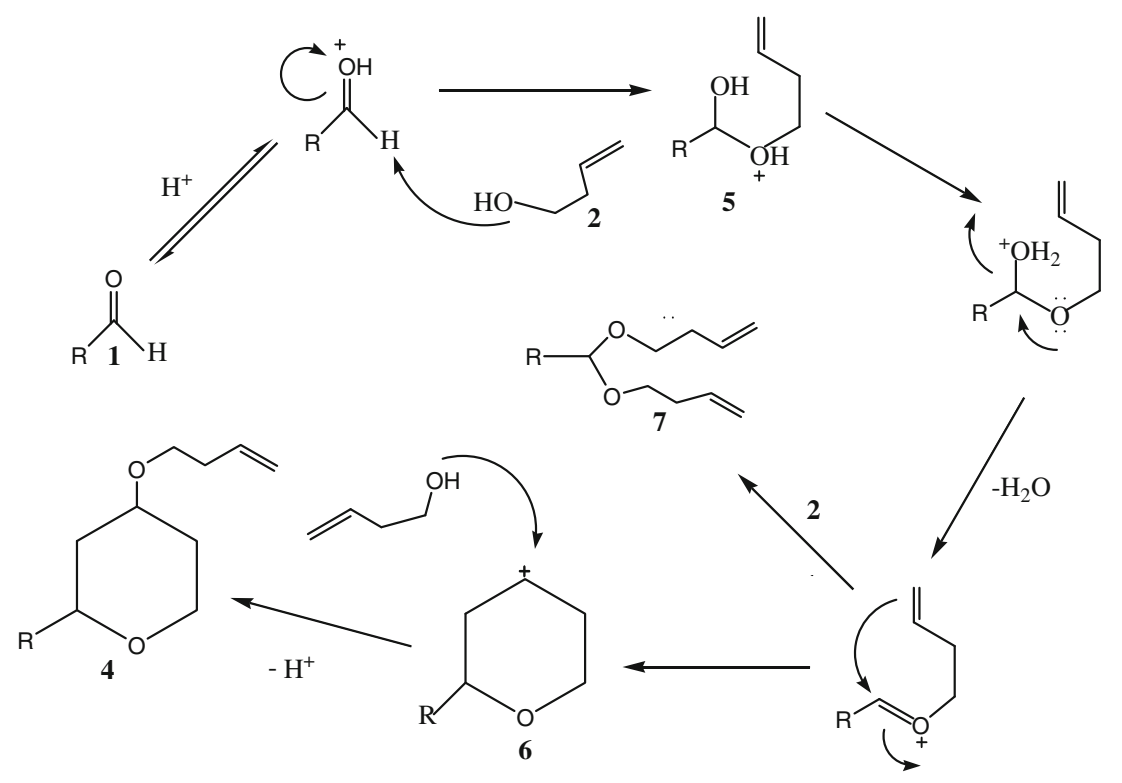

Scheme 2. The Plausible mechanism for Prins cyclization of 3-butene-1-ol with various aldehydes catalysed by PANI-TsOH and PANI- $\mathrm{FeCl}_{3}$. 
Table 4. Synthesis of 1,3-dioxane using PANI- TsOH and PANI- $\mathrm{FeCl}_{3}$ in dichloromethane.

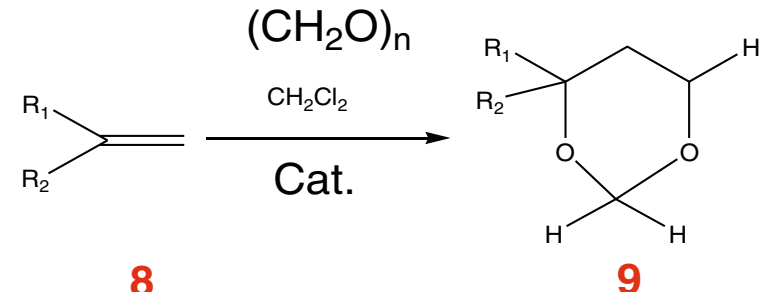

\begin{tabular}{|c|c|c|c|c|c|c|}
\hline Entry & Aldehyde & Alkene & Catalyst & $\begin{array}{l}\text { Temp. } \\
\left({ }^{\circ} \mathrm{C}\right)\end{array}$ & Time (h) & $\begin{array}{l}\text { Product } 9 \\
\text { Yield }(\%)^{\mathrm{a}}\end{array}$ \\
\hline \multirow[t]{2}{*}{1} & \multirow[t]{2}{*}{$\mathrm{HCHO}$} & \multirow[t]{2}{*}{ Styrene } & $\mathrm{TsOH}$ & \multirow[t]{2}{*}{ r.t. } & 1 & 75 \\
\hline & & & $\mathrm{FeCl}_{3}$ & & $45 \mathrm{~min}$ & 85 \\
\hline 2 & $\mathrm{HCHO}$ & Styrene & $\begin{array}{l}\text { PANI-TsOH } \\
\text { PANI- } \mathrm{FeCl}_{3}\end{array}$ & r.t. & 20 & NR \\
\hline 3 & $\mathrm{HCHO}$ & Styrene & PANI-TsOH & 40 & 12 & NR \\
\hline 4 & \multirow{3}{*}{$\begin{array}{l}\text { Formalin } \\
\text { ", }\end{array}$} & \multirow{3}{*}{$\begin{array}{l}\text { ' } \\
\text { Styrene }\end{array}$} & PANI-TsOH & r.t. & 16 & NR \\
\hline \multirow[t]{2}{*}{5} & & & PANI-TsOH & \multirow[t]{2}{*}{40} & 1 & 86 \\
\hline & & & PANI-FeCl 3 & & 1.5 & 80 \\
\hline \multirow[t]{2}{*}{6} & \multirow[t]{2}{*}{$\mathrm{HCHO}$} & \multirow[t]{2}{*}{$\alpha$-methyl styrene } & $\mathrm{TsOH}$ & \multirow[t]{2}{*}{ r.t. } & 1.5 & 70 \\
\hline & & & $\mathrm{FeCl}_{3}$ & & 1 & 82 \\
\hline \multirow[t]{2}{*}{7} & \multirow[t]{2}{*}{$"$} & \multirow[t]{2}{*}{$\alpha$-methyl styrene } & PANI-TsOH & \multirow[t]{2}{*}{40} & 2 & 90 \\
\hline & & & 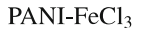 & & 4 & 88 \\
\hline \multirow[t]{2}{*}{8} & \multirow{2}{*}{ Formalin } & \multirow{2}{*}{$\alpha$-methyl styrene } & PANI-TsOH & \multirow[t]{2}{*}{40} & 2 & 70 \\
\hline & & & PANI-FeCl 3 & & 3 & 70 \\
\hline \multirow[t]{2}{*}{9} & \multirow{2}{*}{$\mathrm{HCHO}$} & \multirow{2}{*}{$p$-Chlorostyrene } & $\mathrm{TsOH}$ & \multirow[t]{2}{*}{ r.t. } & 3 & 85 \\
\hline & & & $\mathrm{FeCl}_{3}$ & & 2 & 80 \\
\hline 10 & $\mathrm{HCHO}$ & $p$-Chloro styrene & PANI-TsOH & r.t. & 12 & 85 \\
\hline & & & PANI-FeCl 3 & & & 75 \\
\hline 11 & Formalin & $p$-Chloro styrene & PANI-TsOH & 40 & 12 & NR \\
\hline & & & PANI- $\mathrm{FeCl}_{3}$ & & & \\
\hline 12 & $\mathrm{HCHO}$ & 4-Methoxy styrene & $\mathrm{TsOH}$ & r.t. & 1.5 & 78 \\
\hline & & & $\mathrm{FeCl}_{3}$ & & 1 & 77 \\
\hline 13 & “' & 4-Methoxy styrene & PANI-TsOH & r.t. & 12 & NR \\
\hline & & & PANI- $\mathrm{FeCl}_{3}$ & & & \\
\hline 14 & $\mathrm{HCHO}$ & 1-Octene & $\mathrm{TsOH}$ & r.t. & 2 & 62 \\
\hline & & & $\mathrm{FeCl}_{3}$ & & 1 & 67 \\
\hline 15 & $"$ & 1-Octene & PANI-TsOH & r.t. & 8 & 60 \\
\hline & & & PANI $-\mathrm{FeCl}_{3}$ & & 10 & 60 \\
\hline 16 & $"$ & 1-Octene & PANI - TsOH & 40 & 2 & 80 \\
\hline & & & PANI- $\mathrm{FeCl}_{3}$ & & 2.5 & 78 \\
\hline 17 & Formalin & 1-Octene & PANI-TsOH & 40 & 1 & 80 \\
\hline & & & PANI- $\mathrm{FeCl}_{3}$ & & & 76 \\
\hline
\end{tabular}

a Isolated yields. All products were characterized by FT-IR, ${ }^{1} \mathrm{HNMR}, \mathrm{CHN}$ analyzer and also their comparison with reported data ${ }^{12}$

identified by comparison of their FT-IR, ${ }^{1}$ HNMR spectroscopic data and $\mathrm{CHN}$ analyzer data with those of authentic compounds (prepared by known method) and literature reported data. ${ }^{5,12}$ The polyaniline supported catalysts were prepared using already reported method. ${ }^{10}$

\subsection{Experimental procedure}

3.2a Methods for the preparation of polyaniline supported acid catalysts: The synthesis of polyaniline supported $\mathrm{TsOH}$ and $\mathrm{FeCl}_{3}$ catalysts involved in three steps. The polyaniline salt and base were prepared by aqueous polymerization pathways. (i) Preparation of polyaniline salt. In a $500 \mathrm{ml}$ round bottom flask, $15 \mathrm{ml}$ of sulfuric acid was slowly added to a solution of $350 \mathrm{ml}$ of water with stirring. To the stirring solution, $5 \mathrm{ml}$ of aniline was added and the temperature was maintained at $5-10^{\circ} \mathrm{C}$. The above solution was allowed to continue for stirring for $4 \mathrm{~h}$ in presence of $130 \mathrm{ml}$ aqueous solution of sodium persulfate $(12 \mathrm{gm})$ at $5-10^{\circ} \mathrm{C}$. The precipitated polyaniline powder was filtered and washed with $2 \mathrm{~L}$ distilled water followed by $200 \mathrm{ml}$ acetone. The polyaniline salt powder was dried at $100^{\circ} \mathrm{C}$ till a constant weight.

(ii) Synthesis of polyaniline base. In this step, polyaniline salt powder $(3.5 \mathrm{gm})$ was taken in a 
$500 \mathrm{ml}$ round bottom flask and stirred in $350 \mathrm{ml}$ aqueous sodium hydroxide solution $(1.0 \mathrm{M})$ for $8 \mathrm{~h}$ at ambient temperature. Polyaniline base was precipitated, washed with water and acetone. The base was dried at $100^{\circ} \mathrm{C}$ till a constant weight.

(iii) Redoped polyaniline salt. Initially, $50 \mathrm{ml}$ of $1.0 \mathrm{M}$ two standard solution of PTSA and $\mathrm{FeCl}_{3}$ in acetone was prepared separately. Polyaniline base $(0.5 \mathrm{gm})$ was added to each of the above solution and kept under constant stirring at ambient temperature for $4 \mathrm{~h}$. Solid was filtered, washed with acetone and the solid was dried at $100^{\circ} \mathrm{C}$ till a constant weight. Amount of acid group present in the polymeric chain was calculated based on the weight of redoped polyaniline salt obtained and the weight of poly aniline base used. Amount of dopant present in PANI-TsOH and PANI- $\mathrm{FeCl}_{3}$ were found to be $42.5 \%$ and $29.5 \%$ respectively.

\subsection{Method for preparation of tetrahydropyran derivatives}

A mixture of 3-butene-1-ol (4 mmol), 4-chlorobenzaldehyde $(2 \mathrm{mmol})$ and PANI-TsOH $(0.25 \mathrm{mmol})$ or PANI-FeCl ${ }_{3}(0.25 \mathrm{mmol})$ in dichloromethane $(10 \mathrm{ml})$ was refluxed for the specified reaction period. On completion, as indicated by TLC, the catalyst was filtered and washed with dichloromethane $(2 \times 15 \mathrm{ml})$. The combined organic layers were washed with water, sodium bicarbonate solution, dried over anhydrous sodium sulfate and concentrated in vacuum. The resulting reaction mass was purified by column chromatography on silica gel (Merck,60-120 mesh) using hexane and ethyl acetate as eluent to afford 2,4 disubstituted tetrahydropyran ether as pure product.

\subsection{Method for the preparation of 1, 3-dioxane}

A mixture of styrene $(3 \mathrm{mmol})$ and paraformaldehyde $(3 \mathrm{mmol})$ and PANI-TsOH $(0.25 \mathrm{mmol})$ or PANI- $\mathrm{FeCl}_{3}$ $(0.25 \mathrm{mmol})$ was stirred (refluxed) in dichloromethane at the specified reaction temperature. After completion of the reaction as indicated by TLC, the reaction mixture was filtered, diluted the filtrate with water and extracted with dichloromethane $(2 \times 10 \mathrm{ml})$. The combined organic layers were dried over anhydrous sodium sulfate and distilled under reduced pressure in a rotary evaporator. The crude reaction mixture was further purified by column chromatography using ethyl acetate- $n$-hexane (1:9) as eluent to find pure product 1,3-dioxane.

\subsection{Spectral data of selected compounds}

3.5a cis-2-Phenyl-4-(3-butenoxy)-tetrahydropyran (4a): Light yellow liquid, ${ }^{1} \mathrm{HNMR}\left(400 \mathrm{MHz}, \mathrm{CDCl}_{3}\right) \delta 7.42$ 7.23(m,5H), 5.84(m,1H), 5.13-5.08(m,2H), 4.31(dd, $J=11.3,2.4 \mathrm{~Hz}, 1 \mathrm{H}), 4.22(\mathrm{ddd}, J=11.5,4.2,1.3 \mathrm{~Hz}$, 1H) $3.65(\mathrm{~m}, 1 \mathrm{H}), 3.60(\mathrm{t}, J=6.7 \mathrm{~Hz}, 2 \mathrm{H}), 3.57(\mathrm{~m}, 1 \mathrm{H})$, $2.39(\mathrm{q}, J=6.7 \mathrm{~Hz}, 2 \mathrm{H}), 2.23(\mathrm{~m}, 1 \mathrm{H}), 2.00(\mathrm{~m}, 1 \mathrm{H})$ $1.63(\mathrm{~m}, 1 \mathrm{H}), 1.55(\mathrm{~m}, 1 \mathrm{H})$; IR $(\mathrm{KBr}) \mathrm{cm}^{-1} 1493,1447$, 1350, 1327, 1309, 1165, 1145,1098, 1082,1037, 1021, 986, 954, 907; ${ }^{13} \mathrm{C} \mathrm{NMR}\left(\mathrm{CDCl}_{3}, 400 \mathrm{MHz}, \mathrm{ppm}\right)$ : $\delta=142.1,135.2,128.3,127.7,126.0,116.2,78.2,75.3$, 67.1, 66.0, 40.2, 34.8, 32.5; GC/MS: m/z (\%base peak) $\left(\mathrm{M}^{+}+1,\right), 233,232,177,161,160,159,131,117,105,91$, 77, 71,55(100) CHN Anal. Cal $\mathrm{C}_{15} \mathrm{H}_{20} \mathrm{O}_{2} ; \mathrm{C} 77.55, \mathrm{H}$ 8.68; found C 77. 60, H 8.50

3.5b cis-2-(4-Methylphenyl)-4-(3-butenoxy)-tetrahydropyran (4b): Light yellow liquid, ${ }^{1} \mathrm{HNMR}(400 \mathrm{MHz}$, $\left.\mathrm{CDCl}_{3}\right) \delta 7.30(\mathrm{~d}, J=8.4 \mathrm{~Hz}, 2 \mathrm{H}), 7.20(\mathrm{~d}, J=8.4 \mathrm{~Hz}$, $2 \mathrm{H}), 5.87(\mathrm{~m}, 1 \mathrm{H}), 5.14-5.06(\mathrm{~m}, 2 \mathrm{H}), 4.32(\mathrm{dd}, J=11.2$, $2.0 \mathrm{~Hz}, 1 \mathrm{H}), 4.20(\mathrm{ddd}, J=11.6,4.5,1.7 \mathrm{~Hz}, 1 \mathrm{H})$, $3.64(\mathrm{~m}, 1 \mathrm{H}), 3.57(\mathrm{t}, J=6.9 \mathrm{~Hz}, 2 \mathrm{H}), 3.56(\mathrm{~m}, 1 \mathrm{H})$, $2.38(\mathrm{q}, J=6.9 \mathrm{~Hz}, 2 \mathrm{H}), 2.35(\mathrm{~s}, 3 \mathrm{H}), 2.23(\mathrm{~m}, 1 \mathrm{H})$, $2.03(\mathrm{~m}, 1 \mathrm{H}), 1.64(\mathrm{~m}, 1 \mathrm{H}), 1.56(\mathrm{~m}, 1 \mathrm{H})$; IR $(\mathrm{KBr}) \mathrm{cm}^{-1}$ $1638,1540,1436,1363,1309,1245,1164,1144$, $1108, \quad 1082, \quad 1022, \quad 993, \quad 959 ;{ }^{13} \mathrm{C} \quad \mathrm{NMR}\left(\mathrm{CDCl}_{3}\right.$, $400 \mathrm{MHz}, \mathrm{ppm}): \delta=139.3,137.4,135.3,129.0,126.1$, $116.5,78.2,75.5,67.0,66.4,40.2,34.5,32.8,21.2$; $\mathrm{GC} / \mathrm{MSm} / \mathrm{z}$ (\%base peak)247( $\left.\mathrm{M}^{+}+1\right), 246,245,231$, 205, 175, 174 (100), 173, 159, 146, 145, 129, 121, 120, 119, 118, 105, 93, 87, 77, 71, 55; CHN Anal. Cal $\mathrm{C}_{16} \mathrm{H}_{22} \mathrm{O}_{2}$; C 78.01, H 9.00; found C 78.20, H 9.01.

3.5c cis-2-(4-Chlorophenyl)-4-(3-butenoxy)-tetrahydropyran (4c): Light yellow liquid, ${ }^{1} \mathrm{HNMR}(400 \mathrm{MHz}$, $\left.\mathrm{CDCl}_{3}\right) \delta 7.29(\mathrm{~d}, J=8.3 \mathrm{~Hz}, 2 \mathrm{H}), 7.25(\mathrm{~d}, J=8.3 \mathrm{~Hz}$, $2 \mathrm{H}), 5.84(\mathrm{~m}, 1 \mathrm{H}), 5.13-5.04(\mathrm{~m}, 2 \mathrm{H}), 4.31(\mathrm{dd}, J=11.3$, $2.0 \mathrm{~Hz}, 1 \mathrm{H}), 4.19(\mathrm{ddd}, J=11.3,4.8,1.7 \mathrm{~Hz}, 1 \mathrm{H})$, $3.61(\mathrm{~m}, 1 \mathrm{H}), \quad 3.57(\mathrm{t}, \quad J=6.7 \mathrm{~Hz}, 2 \mathrm{H}), \quad 3.55(\mathrm{~m}, 1 \mathrm{H})$, $2.34(\mathrm{q}, J=6.7 \mathrm{~Hz}, 2 \mathrm{H}), 2.22(\mathrm{~m}, 1 \mathrm{H}), 2.05(\mathrm{~m}, 1 \mathrm{H})$, 1.58(m,1H), 1.46(m,1H); IR (KBr) $\mathrm{cm}^{-1} 1639,1492$, 1436, 1357, 1309, 1245, 1156, 1108, 1077, 1012, $993 ;{ }^{13} \mathrm{C} \mathrm{NMR}\left(\mathrm{CDCl}_{3}, 400 \mathrm{MHz}, \mathrm{ppm}\right): \delta=140.6$, $135.3,133.1,128.4,127.0,116.2,77.6,75.1,67.0$, $66.2,40.1,34.3,32.6$ GC/MS : $\mathrm{m} / \mathrm{z}$ (\%base peak) 269 $\left(\mathrm{M}^{+}+1\right), 268,266,232,195,194,193(100), 165$, $140,139,128,125,111,103,98,77,71,56,55,43,41$ 
CHN Anal. Cal $\mathrm{C}_{15} \mathrm{H}_{19} \mathrm{O}_{2} \mathrm{Cl}$; C 67.54, H 7.18; found C 67.45, H 7.16

3.5d cis-2-(2-Chlorophenyl)-4-(3-butenoxy)-tetrahydropyran (4d): Light yellow liquid, ${ }^{1} \mathrm{HNMR}(400 \mathrm{MHz}$, $\left.\mathrm{CDCl}_{3}\right) \delta 7.52(\mathrm{dd}, J=7.7,1.9 \mathrm{~Hz}, 1 \mathrm{H}), 7.32-7.15(\mathrm{~m}$, $3 \mathrm{H}), 5.85(\mathrm{~m}, 1 \mathrm{H}), 5.13-5.04(\mathrm{~m}, 2 \mathrm{H}), 4.68(\mathrm{dd}, J=11.5$, $2.0 \mathrm{~Hz}, 1 \mathrm{H}), 4.18(\mathrm{ddd}, J=11.5,4.6,1.4 \mathrm{~Hz}, 1 \mathrm{H})$, $3.67(\mathrm{~m}, 1 \mathrm{H}), 3.59(\mathrm{~m}, 1 \mathrm{H}), 3.52(\mathrm{t}, J=6.9 \mathrm{~Hz}, 2 \mathrm{H})$, $2.37(\mathrm{~m}, 1 \mathrm{H}), 2.31(\mathrm{q}, J=6.9 \mathrm{~Hz}, 2 \mathrm{H}), 2.00(\mathrm{~m}$, $1 \mathrm{H}), 1.62(\mathrm{~m}, 1 \mathrm{H}), 1.28(\mathrm{~m}, 1 \mathrm{H})$; IR $(\mathrm{KBr}) \mathrm{cm}^{-1} 1637$, 1566,1472, 1362, 1247, 1203, 1144,1108, 1082, 1052, 988; CHN Anal. Cal $\mathrm{C}_{15} \mathrm{H}_{19} \mathrm{O}_{2}$ Cl; C 67.54, H 7.18; found $\mathrm{C} 67.57, \mathrm{H} 7.22$

3.5e cis-2-(3-Bromophenyl)-4-(3-butenoxy)-tetrahydropyran (4e): Light yellow liquid, ${ }^{1} \mathrm{HNMR}(400 \mathrm{MHz}$, $\left.\mathrm{CDCl}_{3}\right) \delta 7.50(\mathrm{~s}, 1 \mathrm{H}), 7.36(\mathrm{~d}, J=7.6 \mathrm{~Hz}, 1 \mathrm{H}), 7.23(\mathrm{~d}$, $J=7.6 \mathrm{~Hz}, 1 \mathrm{H}), 7.16(\mathrm{t}, \mathrm{J}=7.6 \mathrm{~Hz}, 1 \mathrm{H}), 5.84(\mathrm{~m}, 1 \mathrm{H})$, $5.10-5.04(\mathrm{~m}, 2 \mathrm{H}), 4.28(\mathrm{dd}, J=11.5,2.0 \mathrm{~Hz}, 1 \mathrm{H}), 4.18$ $(\mathrm{ddd}, J=11.5,4.8,1.6 \mathrm{~Hz}, 1 \mathrm{H}), 3.58(\mathrm{~m}, 1 \mathrm{H}), 3.53(\mathrm{t}$, $J=6.8 \mathrm{~Hz}, 2 \mathrm{H}), 3.48(\mathrm{~m}, 1 \mathrm{H}), 2.30(\mathrm{q}, J=6.8 \mathrm{~Hz}, 2 \mathrm{H})$, $2.20(\mathrm{~m}, 1 \mathrm{H}), 2.02(\mathrm{~m}, 1 \mathrm{H}), 1.62(\mathrm{~m}, 1 \mathrm{H}), 1.45(\mathrm{~m}, 1 \mathrm{H}) ; \mathrm{IR}$ (KBr) $\mathrm{cm}^{-1} 1636,1592,1560,1467,1363,1247,1205$, 1166, 1144, 1107, 1082, 1022, 992; CHN Anal. Cal $\mathrm{C}_{15} \mathrm{H}_{19} \mathrm{O}_{2} \mathrm{Br}$; C 57.89, H 6.15; found C 57.92, H 6.17.

\section{5f Di-(3-butenoxy)methyl-4-nitrobenzaldehyde (7d,} new compound): Colourless liquid, ${ }^{1} \mathrm{HNMR}(400 \mathrm{MHz}$, $\left.\mathrm{CDCl}_{3}\right) \delta 8.09(\mathrm{~d}, J=8.7 \mathrm{~Hz}, 2 \mathrm{H}), 7.58(\mathrm{~d}, J=$ $8.7 \mathrm{~Hz}, 2 \mathrm{H}), 5.75-5.73(\mathrm{~m}, 2 \mathrm{H}), 5.52(\mathrm{~s}, 1 \mathrm{H}), 4.97-5.04$ (m, 4H), 3.47-3.49(m,4H), $2.28(\mathrm{q}, J=6.7 \mathrm{~Hz}, 4 \mathrm{H})$; $\mathrm{IR}(\mathrm{KBr}) \mathrm{cm}^{-1} 2927,2877,1641,1605,1524,1343$, $1203,1103,1055,915,852,717,634,546 ;{ }^{13} \mathrm{C}$ NMR $\left(\mathrm{CDCl}_{3}, 400 \mathrm{MHz}, \mathrm{ppm}\right): \delta=147.9,146.0,145.7$, 135.0, 127.8, 123.4, 116.7, 100.0, 64.8, 34.3; GC/MS: $\mathrm{m} / \mathrm{z}$ (\%base peak) $\left(\mathrm{M}^{+}\right) 277,222,206,176,152,136$, 121, 105, 77, 76, 71, 56, 55(100); CHN Anal. Cal $\mathrm{C}_{15} \mathrm{H}_{19} \mathrm{O}_{4} \mathrm{~N}$; C 64.72, H 6.88, N 5.07; found C 64.90, H 6.85, N 5.05

3.5g Di-(3-butenoxy) methyl-3 nitrobenzaldehyde (7e, new compound): Colourless liquid ${ }^{1} \mathrm{HNMR}(400 \mathrm{MHz}$, $\left.\mathrm{CDCl}_{3}\right) \delta 8.33(\mathrm{~s}, 1 \mathrm{H}), 8.15(\mathrm{~d}, J=7.7 \mathrm{~Hz}, 1 \mathrm{H})$, $7.80(\mathrm{~d}, J=7.7 \mathrm{~Hz}, 1 \mathrm{H}), 7.53(\mathrm{t}, J=7.7 \mathrm{~Hz}, 1 \mathrm{H})$, $5.81-5.82(\mathrm{~m}, 2 \mathrm{H}), 5.60(\mathrm{~s}, 1 \mathrm{H}), 5.07-5.12(\mathrm{~m}, 4 \mathrm{H}), 3.55-$ $3.56(\mathrm{~m}, 4 \mathrm{H}), 2.38(\mathrm{q}, J=6.7 \mathrm{~Hz}, 4 \mathrm{H}) ; \mathrm{IR}(\mathrm{KBr}) \mathrm{cm}^{-1} 2921$, 1704, 1642, 1530, 1473, 1436, 1350, 1206, 1111, 1051, 990, $916 ;{ }^{13} \mathrm{CNMR}\left(\mathrm{CDCl}_{3}, 400 \mathrm{MHz}, \mathrm{ppm}\right): \delta=147.9$, $140.6,134.6,132.6,128.9,123.0,121.7,116.5,99.6$,
64.5, 34.3; GC/MS: m/z (\%base peak) $\left(\mathrm{M}^{+}\right) 277,222$, 206, 205, 176, 153, 152, 136, 121, 105, 77, 57, 55(100); CHN Anal. Cal $\mathrm{C}_{15} \mathrm{H}_{19} \mathrm{O}_{4} \mathrm{~N}$; C 64.70, H 6.86, N 5.07; found $\mathrm{C} 64.90, \mathrm{H} 6.85, \mathrm{~N} 5.05$

3.5h Di-(3-butenoxy) methyl-2nitrobenzaldehyde (7f, liquid, new compound): Colourless liquid, ${ }^{1} \mathrm{HNMR}$ $\left(400 \mathrm{MHz}, \mathrm{CDCl}_{3}\right) \delta 7.81-7.83(\mathrm{~m}, 2 \mathrm{H}), 7.61(\mathrm{t}, J=$ $7.6 \mathrm{~Hz}, 1 \mathrm{H}), 7.43(\mathrm{t}, J=7.6 \mathrm{~Hz}, 1 \mathrm{H}), 6.09(\mathrm{~s}, 1 \mathrm{H}), 5.79-$ $5.86(\mathrm{~m}, 2 \mathrm{H}), 5.07-5.13(\mathrm{~m}, 4 \mathrm{H}), 3.68-3.70(\mathrm{~m}, 2 \mathrm{H}), 3.59-$ $3.61(\mathrm{~m}, 2 \mathrm{H}), 2.39(\mathrm{q}, J=6.7 \mathrm{~Hz}, 4 \mathrm{H}) ; \mathrm{IR}(\mathrm{KBr}) \mathrm{cm}^{-1} 2925$, $1702,1530,1441,1351,1270,1193,1110,1062$, $917 ;{ }^{13} \mathrm{C} \mathrm{NMR}\left(\mathrm{CDCl}_{3}, 400 \mathrm{MHz}, \mathrm{ppm}\right): \delta=148.9$, $134.8,133.1,132.4,129.2,128.1,124.1,116.7,98.3$, 66.9, 34.0; GC/MS: $\mathrm{m} / \mathrm{z}\left(\%\right.$ base peak) $\left(\mathrm{M}^{+}\right) 277,222$, 206, 205, 176, 152, 136, 121, 105, 104, 77, 56, 55(100); CHN Anal. Cal $\mathrm{C}_{15} \mathrm{H}_{19} \mathrm{O}_{4} \mathrm{~N}$; C 65.00, H 6.89, N 5.08; found C 64.90, H 6.85, N 5.05

\section{Conclusion}

This article describes the comparative studies of polyaniline-supported catalyst $\mathrm{TsOH}$ and $\mathrm{FeCl}_{3}$ for the Prins cyclization of homoallylic alcohols with different aromatic aldehyde to afford the corresponding 2,4disubstituted tetrahydropyran derivatives and condensation of olefins with paraformaldehyde to produce 1,3-dioxanes in organic solvents

\section{Acknowledgements}

The authors are thankful to Council of Scientific and Industrial Research (CSIR), New Delhi, India for granting a Research Project No. 32-209/2006(SR) to RB.

\section{References}

1. (a) Adams D R and Bhatnagar S P 1977 Synthesis 10 661; (b) Arundale E and Mikeska L A 1952 Chem. Rev. 51 505; (c) Overman L E and Pennington L D $2003 J$. Org. Chem. 68 7143; (d) Zhang W-C and Li C-J 2000 Tetrahedron 562403

2. (a) Delmas M 1980 Synthesis 11 871; (b) Delmas M and Gaset A 1981 Tetra. Lett. 22 723; (c) Bach T and Lobel J 2002 Synthesis 17 2521; (d) Li G, Gu Y, Ding Y, Zhang H, Wang J, Gao Q, Yan L and Suo S 2004 J. Mol. Catal. A: Chem. 218 147; (e) Sreedhar B, Swapna V, Sridhar C, Saileela D and Sunitha A 2005 Syn. Commun. 35 1177; (f) Gu Y, Ogawa C and Kobayashi S 2006 Chem. Lett. 35 1176; (g) Gu Y, Karam A, Jerome F and Barrault J 2007 Org. Lett. 93145 ; (h) Reddy S S, Raju B D, Kumar V S, Padmasri A H, Narayanan S and Rao K S R 2007 Catal. Commun. 8 261; (i) Yadav J S, Reddy B V S, Gopal A V H, Kumar G G K S, Madavi C and Kunwar A 
C 2008 Tetra. Lett. 49 4420; (j) Wang W, Shao L, Cheng W, Yang J and He M 2007 Catal. Commun. 9337

3. (a) Zhang W C, Viswanathan G S and Li C J 1999 Chem. Commun. 3 291; (b) Keh C C K, Namboodiri V V, Varma R S and Li C-J 2002 Tetra. Lett. 43 4993; (c) Keh C C K and Li C-J 2003 Green Chem. 5 80; (d) Yadav J S, Subba Reddy B V, Narayana Kumar G G K S and Aravind S 2008 Synthesis 3395

4. (a) Nicolaou K C and Sorensen E J 1996 Classics in Total Synthesis, VCH, Weinheim; (b) Molinski T F 1996 Tetra. Lett. 37 7879; Fusetani N, Shimoda K and Matsunaga S 1993 J. Am. Chem. Soc. 1153977

5. (a) Yadav J S, Reddy B V S, Sekhar K C and Gunasekar D 2001 Synthesis 6 885; (b) Zhang W-C and Li C-J 2000 Tetrahedron $\mathbf{5 6} 2403$

6. (a) Chari M A and Syamasundar K 2005 Catal. Commun. 6 67; (b) Kobayashi S and Nagayama S 1996 J. Org. Chem. $\mathbf{6 1} 2256$

7. (a) Villa de P A L, Alarcon E and Montes de C C 2002 Chem. Commun. 22 2654; (b) Yadav J S, Reddy B V S, Reddy M S and Niranjan N 2004 J. Mol. Catal. A :
Chem. 210 99; (c) Aramendia M A, Borau V, Jimenez C, Marinas J M, Romero F J and Urbano F J 2001 Catal. Lett. 73203

8. Barth M and Rademann J 2004 J. Comb. Chem. 6340

9. (a) Blaz E, Pielichowski J 2006 Molecules 11 115; (b) Lee B, Ko N H, Ahn B S, Cheong M, Kim H S and Lee J S 2007 Bull. Korean. Chem. Soc. 282025

10. (a) Gangadasu B, Palaniappan S, Amarnath C A and Rao VJ 2006 J. Appl. Poly. Sci. 102 1741; (b) Palaniappan S, John A, Amarnath C A and Jayathirtha R V 2004 J. Mol. Catal. A 218 47; (c) Palaniappan S, Saravanan C, Amarnath C A and Jayathirtha R V 2004 Catal. Lett. 97 77

11. Borah K J, Phukan M and Borah R 2008 Synth. Commun. 383082

12. (a) Tateiwa J, Hashimoto K, Yamauchi T and Uemura $S$ 1996 Bull. Chem. Soc. Jpn. 69 2361; (b) Chandrasekhar S and Reddy B V S 1998 Synlett. 8 851; (c) Yadav J S, Reddy B V S, and Bhaidhya G 2003 Green Chemistry 5 264; (d) Du Y and Tian F 2007 Catal. Commun. 8 2012 